\title{
KENDALA PEMBELAJARAN SASTRA BAGI GURU BAHASA INDONESIA DI SMP NEGERI 43 KONAWE SELATAN
}

\author{
${ }^{1}$ Indra Saskia, ${ }^{2}$ Sahlan, ${ }^{3}$ La Yani Konisi \\ pbsi.fkip.uho@gmail.com
}

${ }^{1,2,3}$ Jurusan Pendidikan Bahasa dan Sastra Indonesia,

Fakultas Keguruan dan Ilmu Pendidikan, Universitas Halu Oleo

Kampus Hijau Bumi Tridharma Anduonohu, Kendari, Indonesia

\begin{abstract}
ABSTRAK
Tujuan dalam penelitian ini adalah untuk mendeskripsikan yang menjadi kendala pembelajaran sastra bagi guru Bahasa Indonesia di SMP Negeri 43 Konawe Selatan. Jenis penelitian yang digunakan dalam penelitian ini tergolong dalam penelitian lapangan sebab peneliti turun langsung ke lokasi untuk mengumpulkan data yang sesuai dengan masalah penelitian. Metode yang digunakan dalam penelitian ini adalah metode deskriptif kualitatif yaitu peneltian yang bertujuan untuk menggambarkan kendala pembelajaran sastra bagi guru Bahasa Indonesia di SMP Negeri 43 Konawe Selatan. Sumber data dalam penelitia ini terdiri dari tiga guru Bahasa Indonesia, sembilan siswa SMP Negeri 43 Konawe Selatan, kepala SMP Negeri 43 Konawe Selatan, dan petugas perpusakaan. Instrumen dalam penelitian ini adalah berupa pedoman observasi, wawancara, dan angket untuk mengetahui kendala pembelajaran sastra bagi guru bahasa Indonesia di SMP Negeri 43 Konawe Selatan. Hasil penelitian menemukan lima faktor yang menjadi kendala pembelajaran sastra bagi guru bahasa Indonesia di SMP Negeri 43 Konawe Selatan. Kendala pembelajaran sastra ditinjau dari guru adalah (1) kurangnya pemahaman guru dalam pembelajaran sastra, (a) tidak adanya pengalaman guru bahasa Indonesia mengikuti pelatihan yang membahasa khusus pembelajaran sastra, (b) guru bahasa Indonesia sering mengunakan salah satu metode dalam pembelajaran sastra, (c) guru sebagian besar sudah menguasai materi pembelajaran sastra, (2) kendala pembelajaran sastra ditinjau dari siswa di SMP Negeri 43 Konawe Selatan, (a) masih kurang pemahaman siswa dalam pembelajaran sastra, (b) kurang ketidaksiapannya aspek psikologi siswa, (c) siswa kurang memiliki minat dan bakat terhadap pembelajaran sastra, (d) siswa jarang membaca buku-buku tentang sastra (3) kendala pembelajaran sastra ditinjau dari sarana prasarana, (a) kondisi perpustakaan di SMP Negeri 43 Konawe Selatan yang tidak menunjang dalam pembelajaran sastra, (b) tidak tersedia media yang akan diterapkan dalam pembelajaran, (c) tidak tersedia sanggar praktek, (4) kendala pembelajaran sastra bagi guru bahasa Indonesia di SMP Negeri 43 Konawe Selatan ditinjau dari faktor kurikulum, (5) faktor yang dominan yang menjadi kendala pembelajaran sastra bagi guru bahasa Indonesia di SMP Negeri 43 konawe Selatan yaitu: (a) faktor guru itu sendiri, (b)faktor sarana prasarana.
\end{abstract}

Kata Kunci : kendala, pembelajaran, sastra 


\section{PENDAHULUAN}

Pendidikan adalah suatu proses dalam rangkah mempengaruhi siswa agar dapat menyesuaikan diri sebaik mungkin terhadap lingkungan dan dengan demikian akan menimbulkan perubahan dalam dirinya yang memungkinkannya untuk berfungsi secara adekuat dalam kehidupan masyarakat. Pengajaran bertugas mengarahkan proses ini agar sasaran dari perubahan itu dapat tercapai sebagaimana yang diinginkan. Kurikulum adalah alat untuk mencapai tujuan pendidikan nasional. Kurikulum merupakan program atau pedoman yang harus dilaksanakan oleh guru dan murid dalam proses belajar mengajar guna mencapai tujuan pendidikan.

Pelaksanaan pembelajaran sastra pada jenjang SMP/MTs belum bisa dikatakan ideal atau memenuhi standar maksimal yang diharapkan. Karena adanya faktorfaktor yang menyebabkan pembelajaran sastra kurang mengarah dari kata ideal dan apresiasif, antara lain faktor internal dan eksternal yaitu saran dan prasaran, dan sastra sangat membutuhkan perhatian yang serius terutama dari guru bahasa itu sendiri. Sampai sekarang belum mencapai sasaran yang maksimal.

Berdasarkan observasi awal di SMP Negeri 43 Konawe Selatan, tanggal 19 Oktober 2019. SMP Negeri 43 Konawe Selatan merupakan salah satu sekolah yang berada di daerah pedesaan. Berdasarkan observasi yang dilakukan di SMP Negeri 43 Konawe Selatan mengalami banyak kendala dalam pembelajaran sastra, dari segi pengajar (guru) banyak mengalami kendala mulai dari guru yang hanya memenuhi kebutuhankurikulum dan tidak memiliki minat terhadap sastra itu sendiri. Dari segi siswa yang kurang memiliki minat untuk belajar sastra karena pembelajaran sastra yang kurang menarik. Dari segi sarana dan prasana yang sangat tidak mendukung dalam pembelajarn sastra karena minimnya sarana pendukung khususnya pembelajaran sastra. Kurangnya buku-buku penunjang yang disediakan perpustakan belum bisa meenuhi kebutuhan siswa khususnya buku yang berkaitan dam pembelajaran sastra. Ketika melakukan obsevasi awal pada perpustakaan buku-buku yang ada dalam perpustakaan khususnya buku sastra bisa dikatakan tidak layak. Hal ini dikarenakan buku-buku tersebut sudah dimakan rayap dan halaman buku tersebut sudah tidak utuh lagi untuk dibaca.

Berdasarkan uraian masalah dalam penelitian ini dilakukan seperti berikut ini:

1. Kendala apa saja yang dialami guru bahasa Indonesia dalam pembelajaran sastradi SMP Negeri 43 Konawe Selatan?

2. Kendala apakah yang dominan dialami guru bahasa Indonesia dalam pembelajaran sastra?

Tujuan dalam penelitian adalah sebagai berikut ini:

1. Mendeskripsikan kendala pembelajaran sastra bagi guru bahasa Indonesia di SMP Negeri 43 Konawe Selatan.

2. Mendeskripsikan kendala yang dominan dialami guru bahasa Indonesia dalam pembelajaran sastra di SMP Negeri 43 Konawe Selatan.

Manfaat yang diharapkan dalam penelitian ini adalah sebagai berikut:

1. Sebagai masukan bagi guru dalam upaya mengatasi kendala yang dialami terhadap pembelajaran sastra khususnya pada SMP Negeri 43 Konawe Selatan.

2. Sebagai upaya untuk membina dan mengembangkan pembelajaran sastra yang lebih baik lagi.

3. Sebagai bahan informasi dalam penelitian selanjutnya yang sifatnya lebih mendalam tentang hambatan guru bahasa indonesia dalam pembelajaran sastra.

Ketidaktercapaian pengajaran sastra yang digelar persekolahan kita sudah barang tentu disebabkan oleh sejumlah faktor. Menurut Suryatin (Mukhlis, 2016: 
68) mengidentifikasi tiga faktor, yakni faktor guru, faktor siswa, dan faktor sarana. Komponen sekolah paling utama yang menghambat proses belajar mengajar selain guru adalah peserta didik. Permasalahan seperti ini diperparah lagi oleh komponen pokok sekolah yang lain, yakni guru yang tidak memiliki inovasi dalam membelajarkan sastra.

Berdasarkan penjelasan tersebut maka dapat ditarik kesimpulan bahwa kendala dalam pembelajaran sastra sehingga belum bisa dikatakan mengenai sasaran karena terdapat beberapa faktor internal penghambat yaitu faktor guru, faktor siswa, dan faktor saran dan prasaran.

Rusman (2018:84) Pembelajaran merupakan suatu sistem, yang terdiri berbagai komponen yang saling berhubungan satu dengan yang lain. Komponen tersebut meliputi: tujuan, materi, metode, dan evaluasi.

Berdasarkan penjelasan tersebut, maka dapat ditarik kesimpulan bahwa pembelajaran adalah kegiatan dua arah, yakni guru sebagai pendidik dan siswa sebagai peserta didik.Kegiatan tersebut menitik beratkan pada siswa dalam kegiatan belajar untuk meningkatkan interaksi siswa dengan guru, dan lingkungan kelas.

Sanjaya (2013: 107), belajar menekankan pada proses mencari dan menemukan pengetahuan melalui interaksi antara individu dengan lingkungannya. Melalui proses tersebut pembelajaran sastra akan mendapatkan pengalaman.

Berdasarkan uraian tersebut dapat disimpulkan bahwa pembelajaran sastra merupakan kegiatan bersastra sehingga siswa dapat menumbuhkan rasa pengertian, penghargaan, kepekaan pikiran kritis, kepekaan perasaan, kepekaan hasrat yang baik terhadap suatu karya sastra.

Dalam pembelajaran sastra ada delapan komponen yang saling berpengaruh. Delapan komponen tersebut adalah siswa, guru,tujuan, materi, strategi, metode, dan media, evaluasi. Berikut ini akan dibahas secara lebih rinci masing-masing komponen pembelajaran.

Siswa adalah organisme yang unik yang berkembang secara sesuai dengan tahap perkembangannya. Perkembangan akan adalah perkembangan seluru aspek kepribadiannya, akan tetapi tempo dan irama perkembangan masing-masing anak pada setiap aspek tidak selalu sama. Proses pembelajaran dapat dipengaruhi oleh perkembangan anak yang tidak sesuai itu, di samping karakteristik lain yang melekat pada diri anak, Zubaedi (2013: 17).

Berdasarkan pendapat tersebut dapat disimpulkan bahwa siswa adalah organisme yang dalam proses pertumbuhan baik dalam psikologi maupun fisik. Menurut Aminuddin (Suhertuti, 2017: 172) ada dua tugas guru dalam kegiatan apresiasi yaitu, mengembangkan pengetahuan dan pengalaman siswa dan membimbing cara berpikir pada waktu apresiasi. Untuk mencapai kompetensi tersebut guru harus dapat mengembangkan pembelajaran sastra sesuai kompetensi yang ada pada kurikulum.

Berdasarkan paparan tersebut dapat disimpulkan bahwa guru adalah orang yang bertanggung jawab dalam proses pembelajaran untuk meningkatkan potensi baik secara sikap, pengetahuan, maupun keterampilan peserta didik.

Kegiatan pembelajaran yang dilaksanakan oleh guru dan siswa adalah kegiatan yang bertujuan.Oleh karena itu, kegiatan tersebut diarahkan pada tujuan yang telah ditentukan.

Berdasarkan paparan tersebut dapat disimpulkan bahwa tujuan merupakan komponen pokok dalam pembelajaran yang harus dirumuskan sejak awal sebelum melakukan proses pembelajara dan acuan atau patokan dalam menjalankan setiap aktivitas. Rumusan tujuan dapat memudahkan siswa dan guru dalam proses pembelajaran sehingga lebih terarah. Siswa lebih mengetahui apa yang harus dipelajari dan guru lebih mudah untuk merencanakan apa yang akan 
diajarkan sehinggapembelajaran lebih optimal.

Isi atau materi pelajaran merupakan komponen kedua dalam sistem pembelajaran.dalam konteks tertentu, materi pelajaran merupakan inti dalam proses pembelajaran. guru perlu secara detail isi materi pelajaran yang harus dikuasai siswa, sebab peran dan tugas guru adalah sebagai sumber belajar (Sanjaya, 2013: 60).

Berdasarkan penjelasan tersebut maka dapat disimpulkan bahawa materi pembelajaran adalah pokok bahasan yang didalamnya terdapat beberapa cakupan pengetahuan, keterampilan, dan sikap untuk mencapai tujuan yang telah ditetapkan.

Rusman (2018: 90) strategi pembelajaran adalah tipe pendekatan yang spesifik untuk menyampaikan informasi, dan kegiatan yang mendukung penyelesaian tujuan khusus. Strategi pembelajaran pada hakekatnya merupakan penerapan prinsi-prinsip psikologi dan prinsip-prinsip pendidikan bagi perkembangan siswa.

Ada empat strategi dasar dalam pembelajaran, yaitu: 1) mengidentifikasi apa yang diharapkan, 2) memilih sistem pendekatan, 3) memilih dan menetapkan prosedur, metode, dan teknik pembelajaran, dan 4) menetapkan normanorma dan batas minimal keberhasilan (Iskandarwasid dan Sunendra, 2015: 8). Berdasarkan pendapat ini, maka strategi pengajaran bisa dikatakan meliputi kegiatan-kegiatan menetapkan pendekatan, metode, teknik, dan standar keberhasilan.

Berdasarkan penjelasan tersebut maka dapat disimpulkan bahwa strategi pembelajaran sastra adalah pendekatan atau taktik yang dilakukan dalam menyampaikan informasi, sehingga dapat mencapai tujuan yang telah ditetapkan.

Beberapa metode pembelajaran yang bisa digunakan untuk mencapai tujuan pembelajaran sastra menurut Sanjaya (2013: 147-159), antara lain:
1. Metode ceramah, yaitu cara menyajikan pelajaran melalui penuturan secara lisan atau penjelasan langsung kepada sekelompok orang.

2. Metode demonstrasi, yaitu penyajian pelajaran sastra pelajaran sastra dengan memperagakan dan mempertunjukkan suatu proses, atau benda tertentu, baik sebenarnya atau hanya sekedar tiruan.

3. Metode diskusi, yaitu metode pembelajaran yang menghadapkan siswa pada suatu permasalahan.

4. Metode simulasi, yaitu metode mengajar, simulasi dapat diartikan cara penyajian pengalaman belajar dengan menggunakan situasi tiruan untuk memahami tentang konsep, prinsip, atau keterampilan tertentu.

Kata media berasal dari bahasa latinmedium yang secara harfiahnya berarti tengah, pengantar, atau perantarah, Munadi (Sufanti, 2010: 61). Pendapat seperti ini juga dikemukakan oleh Bretz (Anita, 2008: 10) bahwa media adalah suatu yang terletak di tengah-tengah, jadi suatu perantara. Berdasarkan pengertian ini, maka media dapat dikatakan sebagai perantara pesan .

Berdasarkan penjelasan di atas dapat disimpulkan bahwa media adalah suatu alat yang digunakan untuk menyampaikan informasi atau pesan-pesan dari sumber (guru) ke penerima (siswa), yang memiliki manfaat dan pengaruh yang sangat besar dalam pembelajaran sastra.

Menurut Rusman (2018: 90), evaluasi merupakan alat indikator untuk menilai pencapaian tujuan-tujuan yang telah ditentukan serta menilai proses pelaksanaan mengajar secara keseluruhan.

Berdasarakan pendapat tersebut maka dapat disimpulkan bahwa evaluasi pembelajaran adalah suatu proses merencanakan, memeroleh, dan menyediakan informasi atau data yang diperlukan dengan cara sistematis untuk menentukan atau membuat keputusan tentang ketercapaian tujuan pengajaran.

Roy Kelem (Rusman, 2018: 209) mencatat bahwa terdapat dua pendekatan 
dalam pembelajaran, pendekatan yang berpusat pada guru (teacher-contered approaches) dan pendekatan yang berpusat pada siswa (student-centered approaches). Pendekatan yang berpust pada guru menurunkan strategi pembelajaran langsung (direct instruction), pembelajaran deduktif atau pembelajaran ekspositori. Adapun, pendekatan pembelajaran yang berpusat siswa menurunkan strategi pembelajaran inkuri dan diskoveri serta pembelajaran induktif.

Telah dikatakan bahwa pembelajaran adalah suatu proses yang menimbulkan terjadinya perubahan dalam tingkah laku dan melibatkan banyak faktor secara garis besarnya. Faktor itu berasal dari dalam individu dan dari luar individu:

Menurut Sanjaya (2013) faktor-faktor itu adalah:

1. Faktor Guru

Guru adalah komponen yang sangat menentukan dalam implementasikan suatu strategi pembelajaran. Tanpa guru, bagaimanapun bagus dan idealnya suatu strategi, maka strategi itu tidak mungkin bisa diaplikasikan.

2. Faktor Siswa

Siswa adalah organisme yang unik berkembang dengan tahap perkembangannya. Perkembangn anak adalah perkembangan seluruh aspek kepribadiannya, akan tetapi tempo dan irama perkembangan masing-masing anak pada setiap aspek tidak selalu sama.

3. Faktor Sarana dan Prasaran

Sarana adalah segala sesuatu yang mendukung secara langsung terhadap kelancaran proses pembelajaran, misalnya media pemebalajaran, alatalat pelajaran, perlengkapan sekolah, dan lain sebagainnya; sedangkan prasaran adalah segala sesuatu yang secara tidak langsung dapat mendukung keberhasilan proses pembelajaran, misalnya jalan menuju sekolah, penerangan sekolah, kamar kecil, dan lain sebagainnya.

4. Faktor Lingkungan
Faktor lingkungan sangat mempengaruhi siswa dalam mempengaruhi pembelajaran sastra. Adapun faktor lingkungan tersebut antara lain:

a. Lingkungan masyarakat yang menjadi kendala guru dalam pelaksanaan pembelajaran sastra.

b. Lingkungan keluarga yang dapat menjadikan kendala adalah status sosial ekonomi orang tua.

c. Lingkungan alamiah yang menjadi kendala dalam pemblajaran sastra yaitu situasi waktu atau zaman yang melengkapi kehidupan guru tentang sastra, jarak tempat tinggal dan cuaca yang tidak mendukung.

Jenis penelitian ini yang digunakan adalah jenis penelitian lapangan.Prosedur penelitian yang menghasilkan data deskripsi berupa kata-kata atau lisan dari lapangan. Selanjutnya digunakan jenis penelitian jenis kualitatif karena penguraian konsep-konsep dalam hubungan satu sama lain digunakan katakata atau kalimat dalam suatu struktur yang benar serta mempengaruhi pemahaman yang mendalam dan luas.

Metode yang digunakan dalam penelitian ini adalah metode kualitatif. Penelitian yang bertujuan untuk menggambarkan secara utuh dan mendalam tentang realitas sosial dan berbagai fenomena yang terjadi di masyarakat yang menjadi subjek penelitian sehingga tergambarkan ciri, karakter, sifat, dan model dari fenomena tersebut.

Data dalam penelitian ini adalah data tertulis dan data lisan yang berupa kendala pembelajaran sastra bagi guru bahasa Indoensia di SMP Negeri 43 Konawe Selatan.Kendala tersebut diketahui dari hasli observasi, wawancara, dan angket yang diberikan kepada guru.

Sumber data dalam penelitian ini adalah tiga guru bahasa Indonesia SMP Negeri 43 Konawe Selatan, Kepala Sekolah SMP Negeri 43 Konawe Selatan, dan sembilan Siswa SMP Negeri 43 Konawe Selatan. 
Instrumen dalam penelitian ini berupa pedoman wawancara, observasi, dan angket. Hal ini dapat dilihat beberapa kendala guru bahasa Indonesia dalam pembelajaran sastra pada siswa SMP Negeri 43 Konawe Selatan. Kendala tersebut antara lain:

1. Kendala pembelajaran sastra bagi guru bahasa Indonesia SMP Negeri 43 Konawe Selatan yang ditinjau dari faktor guru itu sendiri.

2. Kendala pembelajaran sastra bagi guru bahasa Indonesia SMP Negeri 43 Konawe Selatan yang ditinjau dari faktor siswa itu sendiri.

3. Kendala pembelajaran sastra bagi guru bahasa Indonesia SMP Negeri 43 Konawe Selatan yang ditinjau dari faktor saran dan prasarana.

4. Kendala pembelajaran sastra bagi guru bahasa Indonesia di SMP Negeri

43 Konawe Selatan ditinjau dari faktor kurikulum.

Data penelitian ini dikumpulkan dengan teknik observasi, wawancara, angket, dan dokumentasi.

Nasution (1988) menyatakan bahwa observasi adalah dasar semua ilmu pengetahuan.Para ilmuwan hanya dapat bekerja berdasarkan data, yaitu fakta mengenai dunia kenyataan yang diperoleh melalui observasi. Dalam observasi ini peneliti terlibat dengan kegiatan sehari-hari orang yang sedang diamati atau yang digunakan sebagai sumber data peneliti.

Wawancara adalah teknik pengumpulan data yang digunakan peneliti untuk mendapatkan keterangan-keterangan lisan melalui bercakap-cakap dan berhadapan muka dengan orang yang dapat memberikan keterangan kepada peneliti. Wawancara ini dapat dipakai untuk melengkapi data yang diperoleh melalui observasi. Dalam hal ini peneliti menggunakan wawancara terstruktur yaitu pewawancara sudah menyiapkan pedoman wawancara tertentu agar wawancara tidak menyimpang dari tujuan.

Angket yaitu instrumen tertulis yang terdiri dari sejumlah pertanyaan yang digunakan untuk memperoleh informasi dari responden secara tertulis berkaitan dengan hal-hal yang diketahui responden. Angket tidak mengukur pengetahuan, namun dapat digunakan untuk mengetahui informasi mengenai suatu masalah atau pendapat responden. Pada penelitian ini, menggunakan angket tertutup peneliti membuat sejumlah daftar pertanyaan yang kemudian diedarkan dan di jawab oleh responden. Pertanyaan dalam angket tersebut diberikan kedapa guru bahasa Indonesia sehubung dengan hambatan guru bahasa Indonesia dalam pembelajaran sastra di SMP Negeri 43 Konawe Selatan.

Metode dokumentasi adalah teknik pengumpulan data dengan melihat sumbersumber dokumen yang ada kaitannya dengan jenis data yang diperlukan cara efisien yaitu mengambil dokumen untuk melengkapi kekurangan dan kelemahan metode wawancara dan observasi.

Teknik analisis data dalam penelitian ini menggunakan analisis data model Miles dan Huberman. Adapun langkah-langkah yang digunakan oleh peniliti dalam analisis data model Miles dan Huberman antara lain:

1. Data Reduksi (Reduction Data)

Data yang diperoleh dilapangan cukup banyak, maka dari itu penelitan perlu mereduksi data.Mereduksi data berarti merangkum, memilih hal-hal yang pokok, memfokuskan pada hal-hal yang penting. Dengan demikian data yang direduksi akan memberikan gambaran yang jelas, dan mempermudah peneliti untuk melakukan pengumpulan data selanjutnya dan mencarinya bila diperlukan.

2. Penyajian Data (Data Display)

Setelah data direduksi, maka selanjutnya adalah mendisplay data atau menyajikan data, dalam penelitian kualitatif penyajian data ini dapat dilakukan dalam bentuk tabel, grafik dan sejenisnya. Melalui penyajian data tersebut, maka data terorganisasikan, tersususn dalam pola 
hubungan, sehingga akan mudah difahami.

\section{Concluction Drawing/Verification}

Langkah ketiga adalah analisis data kualitatif adalah penarikan kesimpulan dan verifikasi.

\section{HASIL PENELITIAN}

Pada umumnya tujuan pokok pembelajaran sastra ialah membina apresiasi sastra siswa, yaitu membina agar siswa memiliki kesanggupan untuk memahami, menikmati dan menghargai suatu cipta sastra. Oleh karena itu, berdasarkan kenyataan di SMP Negeri 43 Konawe Selatan mengalami banyak kendala dalam pembelajaran sastra yang ditemukan oleh guru bahasa Indonesia selaku guru yang mengajarkan pembelajaran sastra di sekolah. Maka pada bagian akan dijabarkan beberapa faktor yang dianggap menjadi kendala guru dalam pembelajaran sastra.

Berdasarkan hasil observasi, angket, dan wawancara yang dilakukan kepada tiga guru bahasa Indonesia di SMP Negeri 43 Konawe Selatan menunjukkan beberapa kendala yang dihadapi guru pada pembelajaran sastra baik ditinjau dari faktor guru itu sendiri. Hal ini dikarenakan setiap guru bahasa Indonesia di SMP Negeri 43 Konawe Selatan memiliki latar belakang pendidikan yang berbeda dan perbedaan tersebut menjadi kendala yang dialami guru bahasa Indonesia dalam mengajar pembelajaran sastra.

Hal tersebut didukung dengan hasil wawancara kepada guru bahasa Indonesia di SMP Negeri 43 Konawe Selatan selaku informan mengatakan bahwa guru sering mengikuti pelatihan tetapi yang membahas tentang sastra itu tidak pernah. Hal ini menjadi kendala guru bahasa Indonesia di SMP Negeri 43 Konawe Selatan karena kurangnya pemahaman guru tentang pembelajaran sastra itu sendiri.

Berdasarkan pengamatan di lapangan ketika guru melakukan proses pembelajaran guru lebih berpatokan penyampaian materi melalui buku paket.
Hal ini dikarenakan guru bahasa Indonesia kurang memahami cara menyajikan materi khususnya pembelajaran sastra yang lebih menarik dan tidak membosankan untuk siswa.

Berdasarkan angket, dari tiga guru bahasa Indonesia di SMP Negeri 43 Konawe Selatan, ketika proses pembelajaran guru selalau menggunakan salah satu metode. Hal tersebut didukung dengan hasil wawancara yang dilakukan kepada guru bahasa Indonesia di SMP Negeri 43 Konawe Selatan sekalu informan dalam penelitian ini menatakan bahwa dalam proses pembelajaran guru bahasa Indonesia selalu menggunakan salah satu metode dalam pembelajaran sastra yaitu menggunakan metode ceramah.

Dari hasil wawancara tersebut di SMP Negeri 43 Konawe Selatan guru bahasa Indonesia masih menggunakan metode lama dalam proses pembelajaran sastra.

Berdasarkan angket, dari tiga guru bahasa Indonesia di SMP Negeri 43 Konawe Selatan selaku responden dalam penelitian ini mengatakan bahwa setiap pembelajaran guru sudah menguasai materi yang akan diajarkan hal tersebut sesuai dengan pengakuan guru bahasa Indonesia selaku informan.

Pernyataan tersebut didukung dengan hasil wawancara dilakukan pada tiga guru bahasa Indonesia di SMP Negeri 43 Konawe Selatan yang mengatakan bahwa guru bahasa Indonesia belum menguasai seluruh aspek yang akan diajarkan hal ini dikarenakan guru bahasa Indonesia tidak pernah mengikuti pelatihan membahas khusus cara mengajar pembelajaran sastra secara menarik sehingga dalam proses pembelajaran tidak monoton dan tidak berfokus pada penyampaian materi pada buku paket.

Berdasarkan hasil wawancara tersebut di SMP Negeri 43 Konawe Selatan guru bahasa Indonesia secara umum belum menguasai pembelajaran sastra hanya poin-poin tertentu . Hal ini dikarenakan guru bahasa Indonesia tidak 
pernah mengikuti pelatihan yang membahas pembelajaran sastra itu sendiri.

Berdasarkan hasil wawancara kepada siswa SMP Negeri 43 Konawe Selatan. Ditemukan beberapa kendala siswa dalam pembelajaran sastra. Salah satu kendalanya adalah cara guru menyajikan pembelajaran sastra tersebut. Ketika siswa diberikan pertanyaan tentang cara guru membawakan materi dalam pembelajaran sastra dari sembilan siswa, melalui fakta di lapangan enam siswa mengatakan bosan dan tidak menarik dalam mengikuti pembelajaran sastra. Ketika melakukan wawancara terhadap siswa, terdapat salah satu siswa yang tidak tahu tentang pembelajaran sastra. Siswa tersebut hanya mengikuti pembelajaran demi mendapatkan nilai dan tidak memahami apa pembelajaran tersebut.

Berdasakan angket, dari tiga guru bahasa Indonesia menujukkan bahwa guru bahasa Indonesia dalam memberikan materi pembelajaran sastra sering disesuaikan dengan aspek psikologi siswa. Hal tersebut sesuai degan pengakuan guru bahasa Indonesa selaku responden dalam penelitian ini. Pernyataan tersebut didukung dengan hasil wawancara yang dilakukan pada tiga guru bahasa Indonesia di SMP Negeri 43 Konawe Selatan mengatakan bahwa ketika proses pembelajaran di kelas khusus pembelajaran sastra guru berharap siswa ikut terlibat baik secara perasaan maupun emosional sehingga dengan cara tersebut membuat siswa lebih mudah memecahkan masalah yang terdapat dalam pembelajaran sastra.

Ketidaksiapan siswa dalam menerima pembelajaran yang diberikan oleh guru ketika proses pembelajaran mempengaruhi daya tangkap anak. Hal ini mengakibatkan siswa lebih banyak diam tidak ada interaksi antara siswa dan guru, siswa dan siswa. Psikologi siswa menjadi kendala sehingga dalam pembelajaran tidak berjalan dengan baik.

Berdasakan angket, menujukkan bahwa siswa di SMP Negeri 43 Konawe Selatan memiliki minat dan bakat terhadap pembelajaran sastra. Dari tiga guru bahasa Indonesia selaku responden dalam penelitian inimengakui bahwa sebagian dari siswa di SMP Ngeri 43 Konawe Selatan memiliki minat terhadap pembelajaran sastra. Hal tersebut didukung dengan hasil wawancara yang dilakukan pada guru bahasa Indonesia di SMP Negeri 43 Konawe Selatan yang mengatakan bahwa ketika proses pembelajaran siswa lebih cenderung diam. kurangnya minat dan bakat siswa dalam pembelajaan sastra sangat berpengaruh dalam pencapaian siswa dalam memahami pembelajaran sastra.

Berdasarkan fakta yang ada di lapangan minat siswa terhadap pembelajaran sastra sangat minim, kurangnya minat membaca siswa, menulis, dan mengapresiasi sastra menjadi kendala tersendiri dalam pembelajaran sastra. Berdasarkan angket, kurangnya minat siswa di SMP Negeri 43 Konawe Selatan terhadap pembelajaran sastra. Menjadi salah satu alasan sehingga siswa jarang memanfaatkan atau membaca buku-buku tentang sastra hal ini dilatarbelakangi ketidakberpihakan fasilitas dan sarana prasarana. Hal tersebut didukung dangan hasil terhadap salah satu guru bahasa Indonesia sekaligus petugas perpustakan di SMP Negeri 43 Konawe Selatan yang mengatakan bahwa siswa di SMP Negeri 43 Konawe Selatan mengisi waktu istirahat dengan bercengkrama dengan temanteman daripada mengunjungi perpustakaan untuk membaca khusus pembelajaran sastra.

Berdasarkan hasil wawancara tersebut membuat siswa lebih banyak meluangkan waktu untuk berkumpul dengan teman-teman daripada mengisi waktu istirahat dengan memanfaatkan perpustaakn untuk membaca buku-buku khusus pembelajaran sastra.

Ketidaktersediaan sarana prasarana di SMP Negeri 43 Konawe Selatan menjadi kendala dalam pembelajaran sastra bagi guru bahasa Indonesia. Hal ini membuat siswa di SMP Negeri 43 Konawe 
Selatan tidak memiliki wadah untuk mengembangkan minat dan bakat siswa dalam pembelajaran sastra. sarana dan prasarana di SMP Negeri 43 Konawe Selatan masih sangat minim terutama pada kondisi perpustakaan yang bisa dikatakan sangat tidak memenuhi kebutuhan belajar siswa.

Berdasarkan hasil angket, guru bahasa Indonesia sering mendapatkan kendala dalam pembelajaran sastra ditinjau dari kondisi perpustakatan. Hal ini dikarenakan kondisi perpustakaan belum bisa dikatakan layak untuk memenuhi kebutuhan siswa khususnya pembelajaran sastra. Hal tersebut didukung dengan hasil wawancara terhadap salah satu guru bahasa Indonesia selaku petugas perpustakaan yang mengatakan bahwa perpustakaan di SMP Negeri 43 konawe Selatan masih sangat minim dari berbagai hal. Mulai dari struktur perpustakaan, perabot, hingga buku-buku penunjang yang digunakan siswa dalam proses pembelajaran khususnya pembelajaran sastra.

Berdasarkan fakta yang di lapangan bahwa perpustakaan di SMP Negeri 43 Konawe Selatan belum bisa memenuhi kebutuan belajar siswa. Hal ini dikarenakan kelengkapan perpustakaan yang seharusnya bisa memenuhi kebutuhan siswa tetapi hal tersebut tidak terjadi dikarenakan kelengkapan mulai dari bukubuku penunjang siswa tidak lengkap khususnya pembelajaran sastra itu sendiri. Berdasaran angket, menunjukkan bahwa faktor penggunaan media sering menjadi kendala guru bahasa Indonesia dalam pembelajaran sastra.

Hal tersebut didukung dengan hasil wawancara yang dilakukan pada guru bahasa Indonesia selaku informan dalam penelitian ini mengatakan bahwa guru kadang-kadang menggunakan media teks dalam proses pembelajaran seperti teks yang berisi cerita atau puisi lalu dibagikan setiap siswa atau setiap kelompok untuk didiskusikan.

Berdasarkan, fakta yang terjadi di lapangan fasilitas yang kurang mendukung dan memadai menjadi salah satu kendala guru bahasa Indonesia di SMP Negeri 43 Konawe Selatan sulit menentukan media, dan metode dalam pembelajaran sastra yang tepat untuk meningkatkan prestasi siswa.

Berdasarkan angket, di SMP Negeri 43 Konawe Selatan tidak memiliki sanggar praktek atau laboratorium bahasa. Hal tersebut didukung dengan hasil pengamatan yang dilakukan di SMP Negeri 43 Konawe Selatan. Hal tersebut didukung dengan hasil wawancara yang dilakukan pada salah satu guru bahasa Indonesia selaku kepala sekoah di SMP Negeri 43 Konawe Selatan yang mengatakan bahwa di sekolah tersebut tida memiliki saran yang cukup memadai khususnya penyediaan sanggar praktek atau laboratorium bahasa. Sejauh ini belum tersedianya laboratorium bahasa menjadi kendala pembelajaran sastra di SMP Negeri 43 konawe Selatan. Berdasarkan hasil angket, dari tiga guru bahasa Indonesia di SMP Negeri 43 Konawe Selatan selaku responden dalam penelitian ini mengakui bahwa dalam penerapan kurikulum 2013 kadang-kadang mendapat kendala pembelajaran sastra.

Berdasarkan angket, dari tiga guru bahasa Indonesia di SMP Negeri 43 Konawe Selatan selaku responden dalam penelitian ini mengakui bahwa dalam pelaksanaan kurikulum 2013 di SMP Negeri 43 Konawe Selatan dalam segi fasilitas sekolah tersebut belum bisa menunjang dalam pembelajaran sastra. Fakta terjadi di lapangan mengalami banyak kendala dalam pembelajaran sastra hal tersebut dilatar belakangi oleh ketidaksiapan sekolah dalam menerapkan kurikulum 2013, hal tersebut ditinjau dari faktor sarana prasarana di SMP Negeri 43 Konawe Selatan sangat tidak mendukung dalam penerapan kurikulum 2013, tidak semua sekolah mampu menyediakan fasilitas yang bisa menunjang kegiantan itu.

Data penelitian ini menunjukkan bahwa kendala pembelajaran sastra bagi 
guru bahasa Indonesia di SMP Negeri 43 Konawe Selatan. Berdasarkan hasil wawancara, angket dan observasi yang diberikan kepada tiga orang guru bahasa Indonesia, sembilan orang siswa, kepala perpustakaan, dan kepala sekolah SMP Negeri 43 Konawe Selatan selaku informan dalam penelitian. Diketahui bahwakendala yang dominan dalam pembelajaran sastra adalah guru itu sendiri dan sarana prasarana.

Faktor guru itu sendiri menjadi kendala yang dominan dalam pembelajaran sastra hal ini dikarenakan dua guru bahasa Indonesia di SMP Negeri 43 Konawe Selatan tidak memiliki latar belakang pendidikan Bahasa Indonesia, kemampuan guru dalam bidang bahasa Indonesia sangat kurang sehingga pemahaman dan penguasaan terhadap sastra sangat rendah. Tidak pernah mengikuti pelatihan yang membahas sastra membuat guru bahasa Indonesia sangat minim pengetahuan tentang sastra. Ketidakberpihakan sarana prasarana di SMP Negeri 43 Konawe Selatan memperparah kendala yang dialami guru bahasa Indonesia di SMP Negeri 43 Konawe Selatan.

Faktor sarana prasarana menjadi kendala yang dominan dalam pembelajaran sastra, hal ini dikarenakan fasilitas yang ada hubungannya dengan pembelajaran sastra yang menyangkut dengan sarana prasarana sangat tidak mendukung pembelajaran sastra. Berdasarkan hasil observasi yang dilakukan sarana pembelajaran sastra sangat tidak mendukung khususnya tidak tersedianya sanggar praktek atau laboratorium bahasa menjadi salah satu kendala yang dominan dalam pembelajaran sastra.Ketika pembelajaran sastra guru hanya berpatokan pada penyampaian materi sedangkan untuk kegiatan praktek di kesampingkan hal ini disebabkan karena tidak adanya sarana yang mendukung untuk mengolah kreatifitas siswa dalam pembelajaran sastra. Berdasarkan hasil angket, guru bahasa Indonesia di SMP Negeri 43 Konawe Selatan mengakui bahwa sering mendapatkan kendala dalam pembelajaran sastra. Hal ini didukung dengan data tertulis berupa hasil angket guru bahasa Indonesia selaku responden dalam penelitian ini. Berdasarkan hasil angket nomor dua, guru bahasa Indonesia di SMP Negeri 43 Konawe Selatan mengakui bahwa kadang-kadang kendala dalam pembelajaran sastra berasal dari guru itu sendiri. Berdasarkan hasil angket, dari tiga guru bahasa Indonesia di SMP Negeri 43 Konawe Selatan, tiga guru mengakui bahwa guru kadang-kadang mengikuti pelatihan guru tetapi tidak pernah mengikuti pelatihan guru bahasa Indonesia yang membahas tentang sastra. Ketika guru mengikuti pelatihan hanya diberi pemahaman tentang bagaimana guru berada didepan siswa.

Berdasarkan hasil angket, dari tiga guru bahasa Indonesia di SMP Negeri 43 Konawe Selatan, bahwa ketika proses pembelajaran guru selalu menggunakan salah satu metode. Hal tersebut didukung dengan data tertulis berupa hasil wawancara dari tiga guru bahasa Indonesia selaku responden atau informan bahwa dalam pembelajaran sastra guru menggunakan metode pengajaran sastra yaitu metode ceramah.

Berdasarkan hasil angket, dari tiga guru bahasa Indonesia di SMP Negeri 43 konawe Selatan selaku responden mengakui bahwa setiap pembelajaran guru sudah menguasai materi yang akan diajarkan. Hal tersebut sesuai dengan pengakuan guru bahasa Indonesia selaku informan dalam penelitian ini. Berdasarkan data tertulis berupa hasil angket nomor enam, dari tiga guru bahasa Indonesia menyatakan bahwa di SMP Negeri 43 Konawe Selatan kadang-kadang mengalami kendala dalam pembelajaran sastra berasal dari siswa. Dari hasil angket, dari tiga guru bahasa Indonesia menujukkan bahwa guru bahasa Indonesia dalam memberikan materi pembelajaran sastra sering disesuaikan dengan aspek psikologi siswa. Hal ini sesuai dengan pengakuan guru bahasa Indonesia selaku 
responden dalam penelitian ini. Berdasarkan hasil angket nomor, menunjukkan bahwa siswa di SMP Negeri 43 Konawe Selatan kadang-kadang memiliki minat dan bakat terhadap pembelajaran sastra. Dari tiga guru bahasa Indonesia selaku responden mengakui bahwa sebagian siswa di SMP Negeri 43 Konawe Selatan memiliki minat dan bakat terhadap pembelajaran sastra.

Berdasarkan hasil

angket, menunjukkkan bahwa siswa di SMP Negeri 43 Konawe Selatan kadang-kadang memanfaatkan atau membaca buku-buku penunjang tentag sastra. Hal tersebut dikarenakan karena kurangnya minat siswa terhadap sastra hal ini dilatar belakangi kurangnya fasilitas, saran dan parasaran yang mendukung untuk mengembangkan minta siswa. Guru bahasa Indonesia di SMP Negeri 43 Konawe Selatan mendapatkan kendala dalam pembelajaran sastra ditinjau dari faktor sarana dan prasarana. Hal ini tampak pada angket nomor sepuluh. Dari tiga orang guru bahasa Indonesia yang menjadi responden dalam penelitian ini mengakui sering mendapatkan kendala dari faktor sarana dan prasarana dalam pembelajaran sastra.

Berdasarkan hasil angket, guru bahasa Indonesia sering mendapatkan kendala dalam pembelajaran sastra ditinjau dari faktor sarana prasarana. Hal ini sesuai dengan jawaban guru bahasa Indonesia selaku responden dalam penelitian ini mengakui bahwa perpustakaan di SMP Negeri 43 Konawe Selatan sangat kurang buku-buku penunjang tentang pembelajaran sastra. Berdasarkan hasil angket, menunjukkan bahwa faktor penggunaan media sering menjadi kendala guru bahasa Indonesia dalam pembelajaran sastra. Dari tiga guru bahasa Indonesia di SMP Negeri 43 Konawe Selatan selaku responden mengakui bahwa sering mendapatkan kendala pada media pembelajaran sastra.

Hal tersebut didukung dengan data berupa hasil wawancara kepada kelapa sekolah SMP Negeri 43 Konawe Selatan selaku informan dalam penelitian ini menyatakan bahwa di sekolah tersebut tidak ada sanggar praktek atau laboratorium bahasa untuk digunakan siswa dalam proses pembelajaran. Berdasarkan hasil angket, dari tiga guru bahasa Indonesia di SMP Negeri 43 Konawe Selatan selaku respondent dalam penelitian ini mengakui bahwa dalam penerapan kurikulum 2013 sering mendapat kendala pembelajaran sastra. Berdasarkan hasil angket, dari tiga guru bahasa Indonesia di SMP Negeri 43 konawe Selatan selaku responden dalam penelitian ini, mengakui bahwa dalam penerapan kurikulum baru yaitu kurikulum 2013 dari segi fasilitas sangat tidak menunjang dalam pembelajaran sastra. Banyaknya cakupan materi dalam kurikulum 2013 menjadi kendala dalam proses belajar. Hal ini dikarenakan banyak materi yang harus didiskusikan tetapi tidak ada bahan ajarnya yang harusnya cari dari buku penunjang untuk dijadikan rujukan.

Berdasarkan data di lapangan berupa hasil observasi, angket, dan wawancara yang dilakukan oleh peneliti di SMP Negeri 43 Konawe Selatan menemukan kendala dalam pembelajaran sastra bagi guru bahasa Indonesia baik ditinjau dari faktor guru itu sendiri, faktor siswa, faktor sarana prasarana, faktor lingkungan, maupun faktor kurikulum. Diketahui bahwa kendala yang dominan dalam pembelajaran sastra adalah faktor guru itu sendiri dan sarana prasarana.

\section{KESIMPULAN}

Kendala yang dirasakan guru bahasa Indonesia dalam pembelajaran sastra di SMP Negeri 43 Konawe Selatan adalah sebagai berikut:

1. Kendala pembelajaran sastra ditinju dari faktor guru itu sendiri, guru bahasa Indonesia di SMP Negeri 43 Konawe Selatan kurangnya penguasaan pembelajaran sastra. Faktor dari siswa, siswa di SMP Negeri 43 Konawe Selatan memiliki keterbatasan untuk mengembangkan minat dan bakat yang 
mereka miliki karena tidak ada wadah untuk meyalurkan aspirasinya.

Faktor dari sarana dan prasarana, tidak tersedianya sarana dan prasarana yang memadai untuk digunakan dalam pembelajaran sastra.Faktor kurikulum ketidaksiapan sekolah dalam pelaksanaan kurikulum 2013 baik secara komponen sekolah maupun sarana prasarana.

2. Berdasarkan keempat faktor tersebut yang menjadi kendala pembelajaran sastra bagi guru bahasa Indonesia di SMP Negeri 43 Konawe Selatan, faktor yang dominan yang menjadi kendala pembelajaran sastra bagi guru bahasa Indonesia adalah faktor guru itu sendiri dan faktor sarana prasarana.

Berdasarkan simpulan tersebut, berikut ini dikemukakan saran guna mengatasi kendala pembelajaran sastra bagi guru bahasa Indonesia di SMP Negeri 43 Konawe Selatan.

1. Guru bahasa Indonesia perlu melakukan penyegaran kemampuan tentang pembelajaran sastra melalui pelatihan guru bahasa Indonesia yang khusus membahas tentang pembelajaran sastra.

2. Perlunya pengembangan dan pengadaan pembaharuan buku-buku kesastraan di perpustaakn sekolah di SMP Negeri 43 konawe Selatan.

3. Guru perlu memberikan tempat atau wadah untuk siswa menyalurkan minat dan bakatnya.

4. Kepala SMP Negeri 43 Konawe Selatan perlu menyediakan fasilitas yang memadai khususnya fasilitas yang menunjang pembelajaran sastra.

\section{REFERENSI}

Indra, Arif. 2014. 5 Rukun Pembelajaran Kurikulum 2013. Palu Barat: Endece Press.

Iskandarwasid, Sunendar. 2015. Strategi Pembelajaran Berbahasa. Bandung: PT Remaja Rosdakarya.

Mukhlis, Abdul. 2016. Pembelajaran Tutor Sebaya Solusi Praktis dalam
Rangka Menyongsong Pembelajaran Sastra yang Menyenangkan Bagi Siswa SMP. Jural Pendidikan Bahasa dan Sastra Indonesia.Volume 1 Nomor 2. September 2016. Page 6872. p-ISSN: 2477-5932. e-ISSN: 2477-846X.

Muslimin.2011. Perlunya Inovasi dalam Pembelajaran Bahasa dan Sastra Indonesia "Solusi Mengatasi Problem Klasik Pengajaran Bahasa dan Sastra Indonesia". Jurnal Bahasa, Sastra, dan Budaya. ISSN 2088-6020.Vol. 1 No. 1. Mei 2011.

Parwanti, Ni Nyoman dkk. 2018. Belajar dan Pembelajaran. Depok: PT RajaGrafindo Persada.

Purba, Antilan. 2008. Esai Sastra Indonesia Teori \& Penulisan. Yogyakarta: Graha Ilmu.

Rusman. 2018. Belajar dan Pembelajaran Berorientasi Standar Proses Pendidikan. Jakarta: Premadamedia Group.

Rusman, dkk.2013. Pembelajaran Berbasis Teknologi Informasi dan Komunikasi. Jakarta: PT Grafindo Persada.

Sanjaya, Wina. 2013. Strategi Pembelajaran Berorientasi Standar Proses Pendidikan. Kencana: Prenadamedia.

Sufanti, Main. 2010. Strategi Pembelajaran Bahasa dan Sastra Indonesia. Surakarta: Pressindo.

Sugiyono. 2014. Metode Penelitian Kuantitatif, Kualitatif, dan $R \& D$. Bandung: Alfabeta.

Sugiyono. 2017. Metode Penelitian Kuantitatif Kualitatif, dan $R \& D$. Bandung: Alfabeta.

Suhertuti. 2017. Persepsi Guru Bahasa Indonesia Terhadap Materi Sastra pada Kurikulum Tingkat Satuan Pendidikan dan Kurikulum 2013. Jurnal Pendidika Bahasa dan Sastra Indonesia.Volume 1 Nomor 2.Desember 2017.e-ISSN: 2580-9040.

Suryaman, Maman. 2018. Pengalaman Membaca Karya Sastra dalam 
Perspektif Pembelajaran.Jurnal Litera. Volume 17 Nomor 1.Maret 2018.

Suyanto.2017. Pengajaran Sastra di Sekolah Menengah Potret Buram Nasib Sastra Kita.Jurnal Pengajaran. Volume 2 Nomor 2. September 2017. E-ISSN 2503-0329.ISSN 25202-5864. Zubaedi. 2011. Desain Pendidikan Karakter. Jakarta: Kencana. 